\title{
References
}

\section{ABBREVIATED REFERENCES}

\author{
Abbreviation used Reference \\ ARMBRÜSTER Christian ARMBRÜSTER, Privatversicherungs- \\ recht (Mohr Siebeck, Tübingen 2013) \\ Armbrüster, ss 6, 7 Christian ARMBrÜster, 'ss 6, 7', in THeO \\ LANGHEID and MANFRED WANDT (eds), \\ Münchener Kommentar zum VVG: Volume 1 \\ (C.H. Beck, Munich 2010) 676 \\ BIRDS \\ JOHN BIRDS, Modern Insurance Law (9th edn \\ Sweet \& Maxwell, London 2013) \\ Chitty on Contracts Hugh Beale (ed), Chitty on Contracts (31st \\ edn Sweet \& Maxwell, London 2012) \\ Clarke \\ MALCOLM ClaRKe, The Law of Insurance \\ Contracts (6th edn Informa, London 2009) \\ Colinvaux \\ DÖRNER \\ ROBERT MERKIN, Colinvaux's Insurance Con- \\ tract Law (9th edn Sweet \& Maxwell, London \\ 2010) \\ HEINRICH DÖRNER, 'Versicherungsrechtliche \\ Aufklärungspflichten' in EGON LORENZ (ed), \\ Karlsruher Forum 2000: Aufklärungspflichten \\ (VVW, Karlsruhe 2001) 39 \\ EBERS \\ MARTIN EBERS, 'ss 6, 7', in HANS-PETER \\ SCHWINTOWSKI and CHRISTOPH BRÖMMEL- \\ MEYER (eds), Praxiskommentar zum \\ Versicherungsvertragsrecht (2nd edn Lexis- \\ Nexis, 2011) 55 \\ FLEISCHER \\ HOLGER FLEISCHER, Informationsasymmetrie \\ im Vertragsrecht. Eine rechtsvergleichende und \\ interdisziplinäre Abhandlung zu Reichweite
}


HERRMANN

LANGHEID und Grenzen vertragsschlußbezogener Aufklärungspflichten (C.H. Beck, Munich 2001)

HARALD HERRMANN, 's 7' in HORST BAUMANN et al. (eds), Bruck/Möller, VVGGroßkommentar (9th edn de Gruyter, Berlin 2008)

THEO LANGHEID, 's 7' in WOLFGANG RÖMER, THEO LANGHEID and ROLAND RIXECKER (eds), Versicherungsvertragsgesetz, (4th edn C.H. Beck, Munich 2014)

LOWRY, RAWLINGS and JOHN LOWRY, PHILIP RAWLINGS and ROBERT MERKIN MERKIN, Insurance Law: Doctrines and Principles (3rd edn Hart, Oxford 2011)

MACDONALD EGGERS and Foss

MacGillivray

MIETTINEN

PEICL

POHLMANN

POHLMANN and SCHÄFERS

PRÖLSS
PETER MACDONALD EGGERS and PATRICK Foss, Good Faith and Insurance Contracts (3rd edn LLP, London 2010)

NiCHOLAS LEGH-JONES, JOHN BIRDS and DAVID OWEN (eds), MacGillivray on Insurance Law (12th edn Sweet \& Maxwell, London 2012)

JOHANnA MiETTINEN, Die vorvertraglichen Pflichten des Versicherers: Wege zu einer bedarfsgerechten Versicherung durch eine rechtsvergleichende Arbeit im finnischen und deutschen Recht (VVW, Karlsruhe 2005) JÜRGEN BASEDOW et al. (eds), Principles of European Insurance Contract Law - PEICL (Sellier, Munich 2009)

Petra POHLMANN, 'ss 6, 7' in Dirk LOOSCHELDERS and PETRA POHLMANN (eds), VVG-Kommentar (2nd edn Heymanns, Cologne 2011) 306

PETRA POHLMANN and DOMINIK SCHÄFERS, 'VVG-Informationspflichtenverordnung' in DIRK LOOSCHELDERS and PETRA POHLMANN (eds), VVG-Kommentar (2nd edn Heymanns, Cologne 2011) 2101

JÜRGEN PRÖLSS, 'ss 6, 7', in Prölss/Martin Versicherungsvertragsgesetz (28th edn C.H. Beck, Munich 2010) 
RIXECKER, s 6

RIXECKER, s 18a

SCHWINTOWSKI, s 6

WANDT
ROLAND RIXECKER, 's 6' in WOLFGANG RÖMER, THEO LANGHEID and ROLAND RIXECKER (eds), Versicherungsvertragsgesetz. (4th edn C.H. Beck, Munich 2014) ROLAND RIXECKER, 's 18a: Beratungspflichten des Versicherers' in ROLAND MiCHAEL BECKMANN and ANNEMARIE MATUSCHEBECKMANN (eds), VersicherungsrechtsHandbuch (2nd edn C.H. Beck, Munich 2009) 952

HANS-PETER SCHWINTOWSKI, 's 6' in HORST BAUMANN et al. (eds), Bruck/Möller, VVGGroßkommentar (9th edn de Gruyter, Berlin 2008)

SCHWINTOWSKI, s 18 HANS-PETER SCHWINTOWSKI, 's 18: Informationspflichten des Versicherers' in ROLAND MiCHAEL BECKMANN and ANNEMARIE MATUSCHE-BECKMANN (eds), Versicherungsrechts-Handbuch (2nd edn C.H. Beck, Munich 2009) 918 MANFRED WANDT, Versicherungsrecht (5th edn Heymanns, Cologne 2010)

\section{OTHER REFERENCES}

AnNe VAN AAKEN, 'Begrenzte Rationalität und Paternalismusgefahr: Das Prinzip des schonensten Paternalismus' in MiCHAEL ANDERHEIDEN et al. (eds), Paternalismus und Recht (Mohr Siebeck, Tübingen 2006) 109 MiCHAEL ADAMS, 'Irrtümer und Offenbarungspflichten im Vertragsrecht' (1986) 186 AcP 453

MATTHEW D. ADLER, 'Bounded Rationality and Legal Scholarship' in MARK D. WhITE (ed), Theoretical Foundations of Law and Economics (CUP, Cambridge 2009) 137

GEORGE A. AKERLOF, 'The Market for Lemons: Quality Uncertainty and the Market Mechanism' (1970) 84 QJEcon 488

DAVID ALLEN, 'Non-Disclosure: Hairshirt or Halo?' (1992) 55 MLR 96

LiSA R. ANDERSON and JeNNIFER M. MELlOR, 'Predicting Health Behaviours with an Experimental Measure of Risk Preference' (2008) 27 JHealthEcon 1260

Peter ANDREWS, 'Did Life and Pensions "Disclosure" Work as Expected?' in FSA Occasional Paper Series No 32 (2009) 
JENNIFER ARLEN, 'Comment: The Future of Behavioral Economic Analysis of Law' $51 \mathrm{~V}$ and L Rev (1998) 1765

Christian ARMBRÜSTER, 'Beratungspflichten des Versicherers nach $§ 6$ VVG n.F: Grundlagen, Reichweite, Rechtsfolgen' (2008) 97 ZVersWiss 425

Christian ARMbrÜster, 'Das Versicherungsrecht im Common Frame of Reference' (2008) ZEuP, 775

Christian ARMBrÜSTER, 'Neue Bedingungen in der Produkthaftpflicht' (2014) VW 70

KENNETH J. ARROW, 'Uncertainty and the Welfare Economics of Medical Care' (1963) 53 AmEconRev 941

KENNETH J. ARROW, 'Is Bounded Rationality Unboundedly Rational? Some Ruminations' in MIE AUgier and JAMES G. MARCH (eds), Models of a Man: Essays in Memory of Herbert A. Simon (MIT Press, Cambridge/Mass 2004) 47

KENNETH J. ARROW and GERARD DEBREU, 'Existence of an Equilibrium for a Competitive Economy' (1954) 22 Econometrica 265

AdELE ATKINSON et al., 'Levels of Financial Capability in the UK: Results of a Baseline Report' (2006) FSA Consumer Research No 47

Mie Augier and James G. MARCh, 'Herbert A. Simon, Scientist' in EAED. (eds), Models of a Man: Essays in Memory of Herbert A. Simon (MIT Press, Cambridge/Mass 2004) 3

STEPHEN M. BAINBRIDGE, 'Mandatory Disclosure: A Behavioral Analysis' (2000) 68 U Cin L Rev 1023

TOM BAKER, 'On the Genealogy of Moral Hazard' (1996) 75 TexLJ 237

Christian von BAR, ERIC Clive and HANS SCHUlte-NölKe (eds), Principles, Definitions and Model Rules of European Private Law: Draft Common Frame of Reference (DCFR) (Sellier, Munich 2009)

MANUEL BAROCH CASTELLVI, VVG-Informationspflichtenverordnung (Nomos, Baden-Baden 2012)

Alan BARron, 'Reasonable Expectations, Good Faith and SelfRegulatory Codes' in Geraint Howells, ANNETTE NORDHAUSEN, DEBORAH PARRY and Christian TwigG-FleSNER (eds), The Yearbook of Consumer Law 2007 (Ashgate, Aldershot 2007) 3

JÜRgEN BARTH and JÜRgEN BENGEL, Prevention through Fear? The State of Fear Appeal Research (Federal Centre for Health Education, Cologne 2000)

JÜRGEN BASEDOW, 'Die Gesetzgebung zum Versicherungsvertrag zwischen europäischer Integration und Verbraucherpolitik' in FRITZ REICHERT-FACILIDES and ANTON K. SCHNYDER (eds), Versicherungsrecht in Europa: Kernperspektiven am Ende des 20. Jahrhunderts (Helbling \& Lichtenhahn, Basle 2000) 13 
JÜRGEN BASEDOW, 'The European Insurance Market, Harmonisation of Insurance Contract Law, and Consumer Policy' (2000-2001) 7 Connecticut Insurance Law Journal 495

JÜRGEN BASEDOW, 'The Case for a European Insurance Contract Code' (2001) JBL 569

JÜRGEN BASEDOW, 'Why Insurance Contract Law in Europe Should be Harmonised' (2002) Nordisk Försäkringstidskrift 31

JÜRGEN BASEDOW, 'Insurance Contract Law as Part of an Optional European Contract Act' (2003) LMCLQ 498

JÜRGEN BASEDOW, 'Ein optionales europäisches Vertragsgesetz: Opt-in, Opt-out, wozu überhaupt?’ (2004) ZEuP 1

JÜRGEN BASEDOW, 'The Optional Application of the Principles of European Insurance Contract Law' (2008) 9 ERA Forum 111

JÜRGEN BASEDOW, 'An Optional European Contract Law and Insurance' in Caroline van Schoubroeck, Wouter Devroe, Koen Geens and JULES STUYCK (eds), Over Grenzen: Liber amicorum Herman Cousy (Intersentia, Antwerpen 2011) 19

JÜRGEN BASEDOW, 'Closing Remarks: Summary and Outlook' in HELMUT HEISS and MANDEEP LAKHAN (eds), Principles of European Insurance Contract Law: A Model Optional Instrument (Sellier, Munich 2011) 95

JÜRGEN BASEDOW, 'Versicherungsvertragsrecht als Markthindernis' (2014) EuZW 1

JÜRGEN BASEDOW and TILL FOCK, (eds), 'Rechtsvergleich' in EAED. (eds), Europäisches Versicherungsvertragsrecht: Vol 1 (Mohr Siebeck, Tübingen 2002) 1

JÜRGEN BASEDOW et al. (eds), Principles of European Insurance Contract Law - PEICL (Sellier, Munich 2009)

Howard Beales, Richard Craswell and Steven C. Salop, 'The Efficient Regulation of Consumer Information' (1981) 24 JLawEcon 491

JACK BeATSON, 'Has the Common Law a Future?' (1997) 56 CLJ 291

JACK BEATSON and DANIEL FrIEDMANN, "From "Classical" to Modern Contract Law' in JACK BEATSON and DANIEL FRIEDMANN (eds), Good Faith and Fault in Contract Law (OUP, Oxford 1997) $14 \mathrm{f}$

GARY S. BECKER, The Economic Approach to Human Behavior (University of Chicago Press, Chicago 1976)

GARY S. BECKER, 'Nobel Lecture: The Economic Way of Looking at Behavior' (1993) 101 JPolEcon 385

GARY S. BECKER, in RICHARD A. EPSTEIN et al., 'The Roundtable Discussion' (1997) 64 U Chi L Rev 1132

GARY S. BECKER and GUITY NASHAT BECKER, The Economics of Life (McGraw-Hill, New York 1997) 
Howard N. BenNeTt, 'Mapping the Doctrine of Utmost Good Faith in Insurance Contract Law' (1999) LMCLQ 165

HOWARD N. BENNETT, The Law of Marine Insurance (2nd edn Oxford University Press, NY 2006)

OMRI BEN-SHAHAR and CARL E. SCHNEIDER, 'The Failure of Mandated Disclosure' (2011) 159 U Pa L Rev 101

ROGER VAN DEN BERGH, 'Wer schützt den europäischen Verbraucher vor dem Brüsseler Verbraucherschutz?' in ClaUS OTT and HANS-BERND SCHÄFER (eds), Effiziente Verhaltenssteuerung und Kooperation im Zivilrecht (Mohr Siebeck, Tübingen 1997) 77

ROGER VAN DEN BERGH and MichAEL LEHMANN, 'Informationsökonomie und Verbraucherschutz im Wettbewerbs- und Warenzeichenrecht' (1992) GRUR Int 588

URS BICHLER and MONIKA BÜTTLER, Information Economics (Routledge, New York 2007)

JOHN BIRDS, Book review (1976) 39 MLR 615

JOHN BIRDS, 'The Statement of Insurance Practice: A Measure of Regulation of the Insurance Contract' (1977) 40 MLR 677

JOHN BIRDS, 'Insurer's Duty of Utmost Good Faith: Damages for Non-Disclosure' JBL (1986) 439

JoHN BIRDS, 'Case Comment: Insurers not Liable in Damages for Failure to Disclose' (1988) JBL 421

JOHN BIRDS, 'Good Faith in the Reform of Insurance Law' (2004) 54 Amicus Curiae 3

GuY Blackwood, 'The Pre-Contractual Duty of (Utmost) Good Faith: The Past and the Future' (2013) LMCLQ 311

DANIEL BLANKENBURG, 'Verzicht auf Beratung und Informationsrechte nach dem neuen VVG' (2008) VersR 1446

MiChAEl J. Borden, 'Mistake and Disclosure in a Model of Two-Sided Informational Inputs' (2008) 73 MoLRev 667

ANDREAS BÖRGER, Sanktionen für die Verletzung vorvertraglicher Informationspflichten: eine Untersuchung gemeinschaftsrechtlicher Vorgaben und deren Umsetzung in Deutschland, Frankreich und Großbritannien (Sellier, Munich 2010)

JOHAN HENDRIK Botes, From Good Faith to Utmost Good Faith in Marine Insurance (Peter Lang, Frankfurt 2005)

OLIVER BRAND, 'Verbraucherschutz im Versicherungsrecht' in EGON LORENZ (ed), Karlsruher Forum 2011: Verbraucherschutz - Entwicklungen und Grenzen (VVW, Karlsruhe 2012) 55

MARTIN BRENNCKE, 'Regulierung der Werbung von Wertpapierdienstleistungsunternehmen: eine Behavioural-FinanceAnalyse' (2014) WM 1017 
STEPHAN BRINK, 'Neuerungen im Versicherungsvertragsrecht' (2007) ZRP 100

CHRISTOPH BRÖMMELMEYER, 'Vorvertragliche Informationspflichten des Versicherers - Insbesondere in der Lebensversicherung' (2009) VersR 584

CHRISTOPH BRÖMMELMEYER, 'Principles of European Insurance Contract Law' (2011) ERCL 445

CHRISTOPH BRÖMMELMEYER, 'Der Königsweg der Information? Informationspflichten auf dem Markt für Finanzinstrumente nach der Richtlinie 2004/39/EG' in THEODOR SIEGEL (ed), Festschrift für Dieter Rückle (Duncker \& Humblot, Berlin 2011) 13

MANFRED BRUHN, Relationship Management: Management of Customer Relationships (Pearson Education, Harlow 2003)

CHRISTOPH Busch, Informationspflichten im Wettbewerbs- und Vertragsrecht: Parallelen im UWG und BGB (Mohr Siebeck, Tübingen 2008)

CHRISTOPHER BUTCHER, 'Good Faith in Insurance Law: A Redundant Concept?' (2008) JBL 375

Francisco CABrillo and SEAN FitzPaTRICK, The Economics of Courts and Litigation (Edward Elgar Publishing, Cheltenham 2008)

FABrizio CAFaggi, ANTONiO Nicita and Ugo Pagano (eds), Legal Orderings and Economic Institutions (Routledge, London 2007)

Guido CAlabresi, The Costs of Accidents: A Legal and Economic Analysis (Yale University Press, New Haven 1970)

Colin Camerer, Samuel Issacharoff, George loewenstein, Ted O'DONOGHUE and MATTHEW RABIN, 'Regulation for Conservatives: Behavioural Economics and the Case for "Asymmetric Paternalism"" (2003) 151 UPaLRev 1211

ANDREW CAPLIN, 'Fear as a Policy Instrument' in GEORge LoEWENSTEIN, DANIEL READ and ROY F. BAUMEISTER (eds), Time and Decision: Economic and Psychological Perspectives on Intertemporal Choice (Russell Sage, New York 2003) 441

Eugene G. Chewning and Adrian M. HARrell, 'The Effect of Information Load on Decision Makers' Cue Utilisation Levels and Decision Quality in a Financial Distress Decision Task' (1990) 15 Accounting, Organisations and Society 527

PIERRE-ANDRÉ CHIAPPORI and BERnhaRd SALANIÉ, 'Testing Contract Theory: A Survey of Some Recent Work' in Mathias DEWATRIPONT, LARS Peter HANSEN and STEPHEN J. TURNOVsky (eds), Advances in Economics and Econometrics: Theory and Applications, Eighth World Congress: Vol I (CUP, Cambridge 2003) 150 
B.-MARKus Clarin et al., 'Personal Messages Reduce Vandalism and Theft of Unattended Scientific Equipment' (2013) 5 Methods Ecol Evol 125

Malcolm Clarke, 'Failure to Disclose and Failure to Legislate: Is it Material? (Part 2)' (1988) JBL 298

MALCOLM ClARKE, 'The Reasonable Expectations of the Insured - in England?' (1989) JBL 389

Malcolm Clarke, 'Insurance Contracts and Non-Disclosure' (1993) LMCLQ 297

MALCOLM ClaRKE, 'Rescission: A Bridge Too Far for Insurance Good Faith?' (2012) LMCLQ 611

Malcolm Clarke and Helmut HeIss, 'Towards a European Insurance Contract Law?' (2006) JBL 600

RonAld H. COASE, ‘The Nature of the Firm' (1937) 4 Economica 386

Ronald H. COASE, 'The Problem of Social Cost' (1960) 3 JLawEcon 1

Ronald H. CoAse, 'Coase on Posner on Coase: Comment' (1993) 143 JITE 96

JoHn C. CoFFEE, 'Market Failure and the Economic Case for a Mandatory Disclosure System' (1984) 70 Va L Rev 717

Nili CoHEN, 'Pre-Contractual Duties: Two Freedoms and the Contract to Negotiate' in JACK BEATSON and DANIEL FRIEDMANN (eds), Good Faith and Fault in Contract Law (OUP, Oxford 1997) 25

Hugh Collins, 'Good Faith in European Contract Law' (1994) 14 OJLS 229

Hugh Collins, The Law of Contract (4th edn LexisNexis, London 2003)

CONSUMER AFFAIRS VICTORIA, 'Cooling-off periods in Victoria: Their Use, Nature, Cost and Implications' (January 2009) Research Paper No. 15

Robert CoOter and ThOMAs Ulen, Law \& Economics (5th edn Pearson, Boston 2008)

HeRMAN COUSY, 'The Principles of European Insurance Contract Law: the Duty of Disclosure and the Aggravation of Risk' (2008) 9 ERA Forum 119

COLIN CROly and Robert MERKIN, 'Doubts About Insurance Codes' (2001) JBL 587

J. DAVID Cummings and NeIl A. DOHERTY, 'The Economics of Insurance Intermediaries' (2006) 73 JR\&I 359

SAMUEL DALE, 'FCA warns against too much disclosure about "emotionally charged" topics' (2013) Money Marketing (issue of 18 April) 62

SAMUEL DALE, 'FCA admits failure over costly disclosure rules' (2013) Money Marketing (issue of 10 October) 1 
IVONnE DELFOS-RoY, 'The PEICL and the Duty of Disclosure' (2011) ERPL 71

FRANCESCO DENOZZA, 'Fairness and Welfare: Are they Really Competing Values?' in FABRIZIO CAFAGGI et al. (eds), Legal Orderings and Economic Institutions (Routledge, London 2007) 154

Donald N. DeWeEs and Michael J. Trebilcock, 'Judicial Control of Standard Form Contracts' in PAUL Burrows and CENTO G. VELJANOVSKI (eds), The Economic Approach to Law (Butterworths, London 1981) 93

StePHEN Diacon and JoHn HASSELDine, 'Framing Effects and Risk Perception: The Effect of Prior Performance Presentation Format on Investment Fund Choice' (2007) 28 J Econ Psychol 31

ERWIN DICHTL and OTMAR ISSING (eds), Vahlens Großes Wirtschaftslexikon: Vol 1 (2nd edn Beck/dtv, Munich 1994)

AleXANDER Dolgin, The Economics of Symbolic Exchange (Springer, Berlin 2009)

HEINRICH DÖRNER and ANSGAR STAUDINGER, 'Kritische Bemerkungen zum Referentenentwurf eines Gesetzes zur Reform des Versicherungsvertragsrechts' (2006) WM 1710

MEINRAD DREHER, Die Versicherung als Rechtsprodukt: die Privatversicherung und ihre rechtliche Gestaltung (Mohr Siebeck, Tübingen 1991)

JEAN NiCOlAS DRUEY, 'Der Informations-Fetischismus' in ERNST A. Kramer, Peter Nobel and Robert WAldburger (eds), Festschrift für Peter Böckli (Schulthess, Zurich 2006) 589

Anthony DugGan, Michael BRyAn and France HANKS, Contractual Non-Disclosure: An Applied Study in Modern Contract Theory (Longman, Melbourne 1994)

Uwe Dulleck and Rudolf Kerschbamer, 'On Doctors, Mechanics, and Computer Specialists: The Economics of Credence Goods' (2006) 44 Journal of Economic Literature 5

JOHn DunT, Marine Cargo Insurance (Informa, London 2009)

DOMINIQUE Y. DUPONT and GABRIEL S. LEE, 'The Endowment Effect, Status Quo Bias and Loss Aversion: Rational Alternative Explanation' (2002) 25 Journal of Risk and Uncertainty 87

FrAnK H. EASTERBROOK and DANIEL R. Fischel, 'Mandatory Disclosure and the Protection of Investors' (1984) 70 Va L Rev 669

MARTIN EBERS, 'Die Reform des VVG vor dem Hintergrund des Gemeinschaftsrechts' in JÜRGEN BASEDOW et al. (eds), Beiträge zur 13. Wissenschaftstagung des Bundes der Versicherten (Nomos, BadenBaden 2004) 
Werner F. EBKe and BetTina M. Steinhauer, 'The Doctrine of Good Faith in German Contract Law' in Jack BEATSON and DANIEL FRIEDMANN (eds), Good Faith and Fault in Contract Law (OUP, Oxford 1995) 171

MARTINA ECKARDT, Insurance Intermediation: An Economic Analysis of the Information Services Market (Physica-Verlag, Heidelberg 2007)

HORST EIDENMÜLLER, Effizienz als Rechtsprinzip: Möglichkeiten und Grenzen der ökonomischen Analyse des Rechts (3rd edn Mohr Siebeck, Tübingen 2005)

HORST EIDENMÜLLER, 'Der homo oeconomicus und das Schuldrecht: Herausforderungen durch Behavioral Law and Economics' (2005) JZ 216

HORST EIDENMÜLLER, 'Die Rechtfertigung von Widerrufsrechten' (2010) 210 AcP 6

HoRST EIDENMÜLlER et al., 'The Proposal for a Regulation on a Common European Sales Law: Deficits of the Most Recent Textual Layer of European Contract Law' (2012) 16 EdinLR 301

MELVIN A. EISENBERG, 'The Bargain Principle and its Limits' (1982) 95 HarvLRev 741

GARY W. Eldred, 'How Wisely do Consumers Select their Property and Liability Insurance Coverages?' (1980) 14 JConsAff 288

DANIEL EllsberG, 'Risk, Ambiguity and the Savage Axioms' (1961) 75 QJEcon 643

KEES ENGEL, 'Breach of Precontractual Information Duty: Article 2:102 and Article 2:104 of the Principles of European Insurance Contract' (2013) 5 ECCL 44

MARKUS ENGLERTH, 'Behavioral Law and Economics: Eine kritische Einführung' in CHRISTOPH ENGEL et al. (eds), Recht und Verhalten (Mohr Siebeck, Tübingen 2007)

MARKUS ENGLERTH, Der beschränkt rationale Verbrecher: Behavioral Economics in der Kriminologie (Lit, Berlin 2010)

MARTin J. EPPLER and JEANNE MENGIS, 'The Concept of Information Overload: A Review of Literature from Organization Science, Accounting, Marketing, MIS, and Related Disciplines' (2004) 20 The Information Society 325

Muriel FABre-Magnan, 'Duties of Disclosure and French Contract Law' in JACK BEATSON and DANIEL FRIEDMANN (eds), Good faith and fault in contract law (OUP, Oxford 1997) 99

EugEnE F. FAMA, 'Market Efficiency, Long-Term Returns, and Behavioural Finance' (1998) 49 J Finan Econ 283

Eugene F. FAMA and ARTHUR B. LAFFER, 'Information and Capital Markets' (1971) 44 J Bus 289 
DANIEL FARBER, 'What (If Anything) Can Economics Say about Equity?' (2003) 101 MichLRev 1791

Michael G. FAURE and HANnEKE A. Luth, 'Behavioural Economics in Unfair Contract Terms' (2011) 34 JCP 337

ATtILA FENYVES, 'Die Informationspflichten des Versicherers' (2009) VR 16

KARL-HEINZ FEZER, 'Aspekte einer Rechtskritik an der economic analysis of law und am property rights approach' (1986) JZ 817

KARL-HEINZ FEZER, 'Nochmals: Kritik an der ökonomischen Analyse des Rechts' (1988) JZ 223

WOLFGANG FIKENTSCHER and ANDREAS HEINEMANN, Schuldrecht (10th edn de Gruyter, Berlin 2006)

Claire FinKElsteIN, 'Is Risk a Harm?' (2003) 151 U Pa L Rev 963

ROBERT FISCHER, 'Treu und Glauben im Versicherungsrecht' (1965) VersR 197

HOLGER FLEISCHER, 'Vertragsschlußbezogene Informationspflichten im Gemeinschaftsprivatrecht' (2000) ZEUP, 772

HOLGER FLEISCHER, 'Informationspflichten im Europäischen Kapitalmarkt- und Verbraucherschutzrecht: Versuch einer Synthese' in HANS SCHUlTE-NÖLKE, REINER SCHUlze and LudOVIC BERNADEAU (eds), Europäisches Vertragsrecht im Gemeinschaftsrecht (Bundesanzeiger Verlag, Cologne 2002) 171

JOHN G. FlEMING, 'Case Comment: Insurer's Breach of Good Faith: A New Tort?' (1992) 108 LQR 357

RUdOLPH FleSCH, 'A New Readability Yardstick' (1948) 32 J Appl Psychol 221

MARCEl Fontaine, 'An Academic View' in Helmut HeISS and MANDEEP LAKHAN (eds), Principles of European Insurance Contract Law: A Model Optional Instrument (Sellier, Munich 2011) 29

MATTEO FORNASIER, '28. versus 2. Regime: Kollisionsrechtliche Aspekte eines optionalen europäischen Vertragsrechts' 76 (2012) RabelsZ 2012, 401

Gordon R. Foxall, Ronald E. Goldsmith and Stephen Brown, Consumer Psychology for Marketing (2nd edn Thomson Business Press, London 1998)

GEORG FrANCK, Ökonomie der Aufmerksamkeit (Hanser, Munich 1998)

Robert H. FranK and CASS R. Sunstein, 'Cost-Benefit Analysis and Relative Position' (2001) 28 U Chi L Rev 323

EINIKO B. FRANZ, 'Das Versicherungsvertragsrecht im neuen Gewand' (2008) VersR 298

DANIEL FRIEDMANN, 'Good Faith and Remedies for Breach of Contract' in Jack BEATSON and DANIEL FRIEDMANN (eds), Good Faith and Fault in Contract Law (OUP, Oxford 1995) 399 
EIRIK G. FURUBOTN and RUDOLF RICHTER, Institutions and Economic Theory: The Contribution of the New Institutional Economics (2nd edn University of Michigan Press, Ann Arbor 2000)

DAVID GAL, 'A Psychological Law of Inertia and the Illusion of Loss Aversion' (2006) 1 JDM 23

HARRIET C. GAMPER, 'How Can Internet Comparison Sites Work Optimally for Consumers?' (2012) 35 JCP 333

BENJAMIN GILLAD and STANLEY KAISH (eds), Handbook of Behavioural Economics (JAI Press, Greenwich 1986)

EDWARD L. GlaESER, 'Paternalism and Psychology' (2006) 73 U Chi L Rev 133

ANTON GraUER, 'Treu und Glauben im Versicherungsverkehr' (1913) ZVersWiss 290

Hugh GRAVELle and RAY ReEs, Microeconomics (3rd edn Financial Times/Prentice Hall, Harlow 2004)

PhILIP GRAVES, Consumer.ology: The Truth about Consumers and the Psychology of Shopping (Brealey Publishing, London 2013)

BRuce C. Greenwald and Joseph E. Stiglitz, 'Externalities in Economics with Imperfect Information and Incomplete Markets' (1986) 101 QJEcon 229

ERIK GRÖNQVIST, 'Does Adverse Selection Matter? Evidence from a Natural Experiment' (2004) SSE/EFI Working Paper Series in Economics and Finance No. 575

Urs Peter Gruber, 'Article 7' in Gralf-Peter Calliess (ed), Rome Regulations: Commentary on the European Rules of the Conflict of Laws (Wolters Kluwer, Alphen aan den Rijn 2010) 157

STEFAN GRUNDMANN and WOLGANG KERBER, 'Information Intermediaries and Party Autonomy: The Example of Securities and Insurance Markets' in STEFAN GRUNDMANn, WolfGang Kerber and STEPHEN Weatherill (eds), Party Autonomy and the Role of Information in the Internal Market (de Gruyter, Berlin 2001) 264

Gillian K. Hadfield, Robert Howse and Michael J. TRebilcock, 'Information-Based Principles for Rethinking Consumer Protection Policy' (1998) 21 JCP 131

MARK A. HALL, Reforming Private Health Insurance (AEI Press, Washington 1994)

JENNIFER HAMILTON and LORNA E. GiLliES, 'The Impact of E-Commerce Developments on Consumer Welfare - Information Disclosure Regimes' (2003) 11 JFR\&C 329

WALton H. HAMilton, 'The Ancient Maxim Caveat Emptor' (1931) 40 Yale LJ 1133 
DAVID HARARI, 'The Role of the Intermediary', in HELMUT HEISS and MANDEEP LAKHAN (eds), Principles of European Insurance Contract Law: A Model Optional Instrument (Sellier, Munich 2011) 75

KARlson C. HARgroves and Michael HARrison SMITH (eds), The Natural Advantage of Nations: Business Opportunities, Innovations and Governance in the 21st Century (Earthscan, London 2005)

BERTRAM HARNETT, 'The Doctrine of Concealment: A Remnant in the Law of Insurance' (1950) 15 LCP 391

STEFAN HAUPT, 'An Economic Analysis of Consumer Protection in Contract Law' (2003) 4 GLJ 1137

BETTINA HEIDERHOFF, Gemeinschaftsprivatrecht (2nd edn Sellier, Munich 2007)

WOLF-RÜDIGER HEILMANN, Informationspflichtenverordnung, Transparenz und Kosten (VVW, Karlsruhe 2008)

HELMUT HEISS, Treu und Glauben im Versicherungsvertragsrecht (Orac, Vienna 1989)

HelMUt HeISS (ed), An Internal Insurance Market in an Enlarged European Union (VVW, Karlsruhe 2002)

HELMUT HEISS, 'Grund und Grenzen der vorvertraglichen Aufklärungspflicht des Versicherers' (2003) 92 ZVersWiss 339

Helmut HeIss, Stand und Perspektiven der Harmonisierung des Versicherungsvertragsrechts in der EG (VVW, Karlsruhe 2005)

HELMUT HEISS, 'Mobilität und Versicherung' (2006) VersR 448

HELMUT HEISS, 'Principles of European Insurance Contract Law (PEICL)' in MARC HENDRIKSE and JAC RINKES (eds), Insurance and Europe (Uitgeverij, Zutphen 2007) 41

Helmut HeISS, 'The Common Frame of Reference (CFR) of European Insurance Contract Law' (2008) 9 ERA Forum 95

HelMut HeISS, 'Introduction' in JÜRGEN BASEDOW et al. (eds), Principles of European Insurance Contract Law - PEICL (Sellier, Munich 2009), xlix

HELMUT HEISS, The Common Frame of Reference (CFR) of European Insurance Contract Law, (2009) EJCCL 2

Helmut HeISS, 'Introduction' in JÜRGEN BASEDOW et al. (eds), Principles of European Insurance Contract Law - PEICL (Sellier, Munich 2009), xlix

Helmut Heiss, Malcolm Clarke and MandeEP LaKhan, 'Europe: Towards a Harmonised European Insurance Contract Law - The PEICL' in JULIAN BURLING and KEVIN LAZARUS (eds), Research Handbook on International Insurance Law and Regulation (Edward Elgar Publishing, Cheltenham 2011) 603 
Helmut Heiss, 'Introduction', in Helmut HeISS and MANDEeP LAKHAN (eds), Principles of European Insurance Contract Law: A Model Optional Instrument (Sellier, Munich 2011) 7

Helmut HeIss, 'Insurance Contract Law Between Business Law and Consumer Protection' in KAREN BROWN and DAVID SNYDER (eds), General Reports of the XVIIIth Congress of the International Academy of Comparative Law (Springer, New York 2012) 335

HELMUT HEISS, 'Optionales europäisches Versicherungsvertragsrecht' (2012) 76 RabelsZ 316

HeLMUT HeISS, 'Angleichung als Legitimationsproblem' in LEANDER D. LOACKER and CORINNE ZELLWEGER-GUTKNECHT (eds), Differenzierung als Legitimationsproblem (Dike, Zurich 2012) 4

Helmut HeISS, 'Pre-Contractual Information Duties of Insurers in EU Insurance Contract Law' (2012) 23 Insurance Law Journal (Australia) 86

Helmut HeISS, 'General Report' in ID. (ed), Insurance Contract Law between Business Law and Consumer Protection (Dike, Zurich 2012) 7

Helmut HeISS and NOEMI Downes, 'Non-optional Elements in an Optional European Contract Law: Reflections from a Private International Law Perspective' (2005) 13 ERPL 693

Helmut Heiss, Malcolm Clarke and Mandeep LaKhan, 'Europe: Towards a Harmonised European Insurance Contract Law - The PEICL' in JULIAN BURLING and KEVIN LAZARUs (eds), Research Handbook on International Insurance Law and Regulation (Edward Elgar Publishing, Cheltenham 2011) 603

DAVID R. HENDERSON (ed), The Concise Encyclopedia of Economics (2nd edn Liberty Fund, Indianapolis 2007)

ThORSTEN HENS and KREMENA BACHMANn, Behavioural Finance for Private Banking (Wiley, Chichester 2008)

CARSTEN Herresthal, 'Consumer Law in the DCFR' in Gerhard WAGNER (ed), The Common Frame of Reference: A View from Law \& Economics (Sellier, Munich 2009) 163

DAVID HERTZELL, 'Insurance Contract Law Reform in England and Scotland - An Update' (2008) 9 ERA Forum 177

DAVID HeRTZELl, 'UK' in Helmut HeISS (ed), Insurance Contract Law between Business Law and Consumer Protection (Dike, Zurich 2012) 355

DAVID HeRTzell, 'The Law Commissions and Insurance Contract Law Reform: An Update' (2013) 19 JIML 105

EDMUND HEWARD, Lord Mansfield (Barry Rose, Chichester 1979)

JoHANNES HEYERS, 'AVB und Beratungspflichten: Markt- und Produktdisposition' (2010) 99 ZVersWiss 349 
Paul Heyne, 'Efficiency' in David R. Henderson (ed), The Concise Encyclopedia of Economics (2nd edn Liberty Fund, Indianapolis 2007) Paul Heyne, Peter J. BoettKe and David L. Prychitko, The Economic Way of Thinking (10th edn Prentice Hall, Upper Saddle River 2003)

Peter HinchlifFe, 'Review of Principles of European Insurance Contract Law' (2008) 9 ERA Forum 167

Peter HinchlifFe, 'The Consumer's View' in Helmut Heiss and MANDEEP LAKHAN (eds), Principles of European Insurance Contract Law: A Model Optional Instrument (Sellier, Munich 2011) 59

NORMA J. HIRD, 'Pan Atlantic - Yet More to Disclose?' (1995) JBL 608

GÜNTER HIRSCH, Erfahrungen des Versicherungsombudsmanns, insbesondere mit der Beratungs- und Dokumentationspflicht (VVW, Karlsruhe 2010)

GÜNTER HIRSCH, 'The German Insurance Ombudsman' (2011) 100 ZVersWiss 561

JACK HIRSHLEIFER, 'Where Are We in the Theory of Information?' (1973) 63 AmEconRev 31

JACK HIRSHLEIFER and JOHN G. RILEY, The Analytics of Uncertainty and Information (CUP, Cambridge 1992)

SusAn Hodges, Law of Marine Insurance (Cavendish, London 1996)

RAY W. HodgIN, Protection of the Insured (LLP, London 1989)

JENS HoFFMANN, 'Elektronische Datenträger als Informationsmedium' (2011) ZVersWiss 745

ERIC M. HolmeS, 'A Contextual Study of Commercial Good Faith: Good-Faith Disclosure in Contract Formation' (1978) 39 U Pitt L Rev 381

GERAINT Howells, 'The Potential and Limits of Consumer Empowerment by Information' (2005) 32 Journal of Law and Society 349

GERAINT HOWELlS and STEPHEN WeATHERILl, Consumer Protection Law (2nd edn Ashgate, Aldershot 2005)

GERAINT HOWELlS and THOMAS WILHELMSSON, 'EC Consumer Law: Has it Come of Age?' (2003) 28 ELR 370

BINGYUAN HSIUNG, 'The Commonality Between Economics and Law' (2004) 18 EJLE 33

Peter H. Huang, 'Regulating Irrational Exuberance and Anxiety in Securities Markets' in FRANCESCO PARISI and VERNON L. SMITH (eds), The Law and Economics of Irrational Behavior (Stanford University Press, Stanford 2005) 501

JÖRG IHLE, Der Informationsschutz des Versicherungsnehmers (Dr. Kovač, Hamburg 2006)

RICHARD A. IPPOLITO, Economics for Lawyers (Princeton University Press, Princeton 2005) 
TERry IsOn, Credit Marketing and Consumer Protection (Croom Helm, London 1979)

RUDOLF VON JHERING, 'Culpa in contrahendo' (1861) 4 JherJb 1

Christine Jolls, CASS R. SUnSTEIN and Richard Thaler, 'A Behavioral Approach to Law and Economics' (1998) 50 StanLRev 1471

Christine Jolls, Cass R. Sunstein and Richard Thaler, 'Theories and Tropes: A Reply to Posner and Kelman' (1998) 50 StanLRev 1593

DANIEL KAHNEMAN and AMOS TVERSKY, 'Prospect Theory: An Analysis of Decision under Risk' (1979) 47 Econometrica 263

DANIEL KAHNEMAN, JACK L. KNETSCH and RichaRD H. THALER, 'Experimental Tests of the Endowment Effect and the Coase Theorem' (1990) 98 JPolEcon 1325

DANIEL KAHNEMAN, JACK L. KNETSCH and RichARD H. THALER, 'Anomalies: The Endowment Effect, Loss Aversion, and Status Quo Bias' (1991) 5 The Journal of Economic Perspectives 193

LOUIS KAPLOW and STEVEn ShaVell, Fairness Versus Welfare (Harvard University Press, Cambridge/Mass 2002)

DAVID S. KELLY, 'The Insured's Rights in Relation to the Provision of Information by the Insurer' (1989) 2 ILJ 45

MARK Kelman, 'Behavioral Economics as Part of a Rhetorical Duet: A Response to Jolls, Sunstein, and Thaler' (1998) 50 StanLRev 1577

FRIEDRICH KESSLER and EDITH FINE, 'Culpa in Contrahendo, Bargaining in Good Faith, and Freedom of Contract: A Comparative Study' (1964) 77 HarvLRev 401

EVA-MARIA KIENINGER, 'Informations-, Aufklärungs- und Beratungspflichten beim Abschluss von Versicherungsverträgen' (1998) 198 AcP 190

EVA-MARIA KIENINGER, 'Informationspflichten als Allheilmittel des Verbraucherschutzrechts?' in Verhandlungen des 69. Deutschen Juristentages 2012: Vol II/1 (C.H. Beck, Munich 2013) I 29

CHRISTOPH KINS, Der Abschluss des Versicherungsvertrags: eine Untersuchung des Zusammenspiels von vorvertraglicher Informationspflicht und Abschlussmodell (VVW, Karlsruhe 2010)

GEBHARD KIRCHGÄSSNER, 'Führt der homo oeconomicus das Recht in die Irre?' (1991) JZ 104

GEBHARD KIRCHGÄSSNER, Homo Oeconomicus (3rd edn Mohr Siebeck, Tübingen 2008)

MARTIN KLAFFKE, Anlagebetrug am Grauen Kapitalmarkt: Theoriebasierte empirische Analyse aus ökonomischer Perspektive (Deutscher Universitätsverlag, Wiesbaden 2002)

LARS KLÖHN, Kapitalmarkt, Spekulation und Behavioral Finance: Eine interdisziplinäre und vergleichende Analyse zum Fluch und Segen der 
Spekulation und ihrer Regulierung durch Recht und Markt (Duncker \& Humblot, Berlin 2006)

DANIEL KOHLERT and ANDREAS OEHLER, 'Scheitern Finanzdienstleistungen am Verbraucher? Eine theoretische Analyse rationale Verbraucherverhaltens im Rahmen des Anlageberatungsprozesses' (2009) 78 Vierteljahreshefte zur Wirtschaftsforschung 81

HEIN KÖTZ, 'Vertragliche Aufklärungspflichten: Eine rechtsökonomische Studie' in JÜRGEN BASEDOW, KLAUS HOPT and REINHARD ZIMMERMANN (eds), Undogmatisches: Rechtsvergleichende und rechtsökonomische Studien aus dreißig Jahren (Mohr Siebeck, Tübingen 2005) 246

WERnER KROEBER-RIEL, PETER WEINBERG and ANDREA GRÖPPELKLEIN, Konsumentenverhalten (9th edn Vahlen, 2009)

WolfGANG KROHN, Francis Bacon (2nd edn C.H. Beck, Munich 2006) ANTHONY T. KRONMAN, 'Mistake, Disclosure, Information, and the Law of Contracts' (1978) 7 JLS 1

Howard KunReuther and MARK PAUly, Role of Deliberative Thinking and Emotions in Insurance Decision Making (working paper, 2014)

Howard C. KunReuther, MARK V. PAULY and STACEY MCMorrow, Insurance and Behavioural Economics: Improving Decisions in the Most Misunderstood Industry (CUP, Cambridge 2013)

PHILIPP KÜSTER, 'Die vorvertragliche Beratungspflicht des Versicherers nach § 6 Abs 1 und 2 VVG' (2010) VersR 730

MANDEEP LAKHAN, 'Report on Discussion II' in HelMUt HEISS and MANDEEP LAKHAN (eds), Principles of European Insurance Contract Law: A Model Optional Instrument (Sellier, Munich 2011) 85

Ole Lando and Hugh Beale (eds), Principles of European Contract Law: Parts I and II (Kluwer Law International, 1999)

Ole Lando, André PrÜM, ERIC Clive and Reinhard ZimmermanN (eds), Principles of European Contract Law: Part III (Kluwer Law International, 2003)

BETTINA LANFERMANN, 'Transparenz durch Ratings? Unternehmensund Produktratings deutscher Nicht-Lebensversicherer' (VVW, Karlsruhe 1998)

THEO LANGHEID, 'VVG-Reform und Verbraucherschutz' in ANSGAR STAUDINGER and THEO LANGHEID, Versicherungsrechtsmodernisierung - Kritikpunkte aus nationalem und europäischem Blickwinkel (VVW, Karlsruhe 2007) 23

PIERRE LEGRAND JR, 'Pre-Contractual Disclosure and Information: English and French Law Compared' (1986) 6 OJLS 322

KATJA LENZING, 'Europäisches Gemeinschaftsrecht' in JÜRGEN BASEDOW and TILL FOCK (eds), Europäisches Versicherungsvertragsrecht: Vol 1 (Mohr Siebeck, Tübingen 2002) 139 
Kent LeVerenz, "Anforderungen an eine "gesonderte Mitteilung" nach dem VVG 2008' (2008)VersR 709

KURT LEWIN, Field Theory in Social Science: Selected Theoretical Papers (Harper, New York 1951)

LEANDER D. LOACKER, 'Insurance Soft Law?' (2009) VersR 289

LEANDER D. LOACKER, 'Einführung in das Europäische Versicherungsvertragsrecht' in DiRK LOOSCHELDERS and PETRA POHLMANN (eds), VVG-Kommentar (2nd edn Heymanns, Cologne 2011) 47

LEANDER D. LOACKER, 'Verhaltensökonomik als Erkenntnisquelle für die Rechtsetzung' in BEA VERSCHRAEGEN (ed), Interdisciplinary Studies of Comparative and Private International Law: Vol III (Jan Sramek, Vienna 2012) 45

LEANDER D. LOACKER, 'Basisinformationen als Entscheidungshilfe' in MANFRED WANDT et al. (eds), Festschrift für Egon Lorenz zum 80. Geburtstag (VVW, Karlsruhe 2014) 259

LEANDER D. LOACKER and VERENA LOACKER, 'Die Richtlinie über unlautere Geschäftspraktiken: Grundkonzeption und Verbraucherleitbild' in LUKAS FAHRLÄNDER and RETO HEIZMANN (eds), Europäisierung der schweizerischen Rechtsordnung (Dike, Zurich 2013) 585

George Loewenstein, Daylian M. Cain and Sunita SaH, 'The Limits of Transparency: Pitfalls and Potential of Disclosing Conflicts of Interest' (2011) 101 AmEconRev 423

DiRK LOOSCHELDERS and LOTHAR MiCHAEL, 'Europäisches Versicherungsrecht' in MATTHIAS RUFFERT (ed), Europäisches Sektorales Wirtschaftsrecht: Vol V (Nomos, Baden-Baden 2013) 671

EGON LORENZ, 'Der Einfluss des allgemeinen Widerrufsrechts in dem Entwurf des Versicherungsvertragsgesetzes 2006 auf den Abschluss von Versicherungsverträgen nach dem Antrags- und Policenmodell' in PETER AlbRECHT, EGON LORENZ and BERND RUdOLPH (eds), Risikoforschung und Versicherung: Festschrift für Elmar Helten (VVW; Karlsruhe 2004) 331

EGON LORENZ, 'Die gewohnheitsrechtliche Erfüllungshaftung des Versicherers im bisherigen und im zukünftigen Versicherungsvertragsrecht' in ANDREAS HELDRICH et al. (eds), FS Canaris (C.H. Beck, Munich 2007) 757

EGON LORENZ (ed), Karlsruher Forum 2011: Verbraucherschutz Entwicklungen und Grenzen (VVW, Karlsruhe 2012)

JOHN LOWRY and PHILIP RAWLINGS, Insurance Law: Doctrines and Principles (2nd edn Hart, Oxford 2005)

BRIGITTA LURGER, Vertragliche Solidarität: Entwicklungschance für das allgemeine Vertragsrecht in Österreich und in der Europäischen Union (Nomos, Baden-Baden 1998) 
BRIGITTA LURGER, Grundfragen der Vereinheitlichung des Vertragsrechts in der Europäischen Union (Springer, Vienna 2002)

BRIGITTA LURGER, "The "Social" Side of Contract Law and the New Principle of Regard and Fairness' in ARTHUR HARTKAMP, MARTIJN HESSELINK and EwOUd HONDIUS et al. (eds), Towards a European Civil Code (Kluwer Law International, Nijmegen 3rd edn 2004) 273

Peter MacDonald EgGers, 'Remedies for the Failure to Observe the Utmost Good Faith' (2003) LMCLQ 249

VANESSA MAK, 'The Myth of the "Empowered Consumer": Lessons from Financial Literacy Studies' (2012) euvr 254

VANESSA MAK and JURGEN BRASPENNING, 'Errare humanum est: Financial Literacy in European Consumer Credit Law' (2012) 35 JCP 307

Robin P. Malloy, Law and Market Economy: Reinterpreting the Values of Law and Economics (CUP, Cambridge 2000)

JonATHAN MANCE, 'In a Manner of Speaking: How Do Common, Civil and European Law Compare?' (2014) 78 RabelsZ 231

JONATHAN MANCE, IAIN GOLDREIN and ROBERT MERKIN (eds), Insurance Disputes (2nd edn LLP, London 2003)

PETER MANKOWsKi, Beseitigungsrechte: Anfechtung, Widerruf und verwandte Institute (Mohr Siebeck, Tübingen 2003)

PETER MANKOWSKI, 'Formation of Contract and Pre-Contractual Duties to Inform in a Comparative Perspective' in STEFAN GRUNDMANN and MARTIN SCHAUER (eds), The Architecture of European Codes and Contract Law (Kluwer, Alphen aan den Rijn 2006) 321

M. Susan MARQuis and Charles E. Phelps, 'Price Elasticity and Adverse Selection in the Demand for Supplementary Health Insurance' (1987) 25 Economic Inquiry 299

ISABEL MATTERN, Das Informationsmodell im VVG unter Berücksichtigung der Auswirkungen auf die AGB-Kontrolle (VVW, Karlsruhe 2011)

PAUl MatTHEWS, 'Uberrima Fides in Modern Insurance Law' in FRANCIS D. Rose (ed), New Foundations for Insurance Law (Stevens \& Sons, London 1987) 39

WOLFGANG MAYERHOFER, Einflussfaktoren auf den Abschluss von Versicherungen und der Beitrag des Versicherungsmaklers (Facultas, Vienna 2009)

William W. McBryde, The Law of Contract in Scotland (3rd edn W. Green, Edinburgh 2007)

ANDREW MCGEE, The Single Market in Insurance: Breaking Down the Barriers (Ashgate, Aldershot 1998)

ANDREW MCGEE, The Modern Law of Insurance (3rd edn LexisNexis, London 2011) 
RICHARD B. MCKENZIE, Predictably Rational? In Search of Defenses for Rational Behavior in Economics (Springer, Berlin 2010)

GERARD MCMeEL, 'The FSA's Insurance Conduct of Business Regime: A Revolution in (Consumer) Insurance Law?' (2005) LMCLQ 186

Nicholas Mercuro and Steven G. Medema, Economics and the Law: From Posner to Post-Modernism (Princeton University Press, New Jersey 1997)

ROBERT MERKIN, 'Uberrimae Fidei Strikes Again' (1976) 39 MLR 478

ROBERT MERKIN, Reforming Insurance Law: Is there a Case for Reverse Transportation? A Report for the English and Scottish Law Commissions on the Australian Experience of Insurance Law Reform (2007)

ROBERT MERKIN, Insurance Law: An Introduction (Informa, London 2007)

ROBERT MERKIN and JOHN LOWRY, 'Reconstructing Insurance Law: The Law Commissions' Consultation Paper' (2008) 71 MLR 95

HANNO MERKT, 'Disclosure Rules as a Primary Tool for Fostering Party Autonomy' in Stefan Grundmann, WolfGang Kerber and StePHEN WeATHERILl (eds), Party Autonomy and the Role of Information in the Internal Market (de Gruyter, Berlin 2001) 230

HANNO MERKT, 'Creditor Protection through Mandatory Disclosure' in HORST EIDENMÜLlER and WOLFGANG SCHÖN (eds), The Law and Economics of Creditor Protection - A Transnational Perspective (Asser Press, The Hague 2008) 94

DAVID DE MEZA and DAVID C. WeBB, Advantageous Selection in Insurance Markets' (2001) 32 RAND Journal of Economics 249

DAVID DE MEZA, Bernd IRlenbusch and DiAne ReYniERs, 'Financial Capability: A Behavioural Economics Perspective' (2008) FSA Consumer Research No 69, 1

ThOMAS J. Miceli, The Economic Approach to Law (Stanford University Press, Stanford 2004)

HANS-W. MiCKLITZ, 'Legitime Erwartungen als Gerechtigkeitsprinzip des europäischen Privatrechts' in LUDWIG KRÄMER, HANS-W. MICKLITZ and KLAUS TONNER (eds), Law and diffuse interests in the European legal order: Liber amicorum Norbert Reich (Nomos, BadenBaden 1997) 245

GeORge A. MiLler, 'The Magical Number Seven, Plus or Minus Two' (1956) 63 Psychol Rev 81

JEREMY MitCHELL, 'Financial Information for Consumers: A Future Strategy for Consumer Organisations' (1988) 11 JCP 85

JAMES MONTIER, Behavioural Investing: A Practitioner's Guide to Applying Behavioural Finance (John Wiley, Chichester 2007) 
THOMAS MÜNKEL, 's 6' in WILFRIED RÜFFER, DIRK HALBACH and PETER SCHIMIKOWSKI (eds), Versicherungsvertragsgesetz - Handkommentar (Nomos, Baden-Baden 2009) 118

MARTIN Nell, ANDREAS RICHTER AND JÖRG Schiller, 'When Prices Hardly Matter: Incomplete Insurance Contracts and Markets for Repair Goods' (2009) 53 EER 343

PHILliP NELSON, 'Information and Consumer Behavior' (1970) 78 JPolEcon 311

Antonio Nicita and Ugo PAgAno (eds), Legal Orderings and Economic Institutions (Routledge, London 2007) 21

ERNST NiEDERLEITHINGER, 'Auf dem Weg zu einer VVG-Reform' (2006) VersR 437

RICHARD NISBETT and LEE ROSS, Human Inference: Strategies and Shortcomings of Social Judgment (Prentice Hall, New Jersey 1980)

JOHN A. NYMAN, The Theory of Demand for Health Insurance (Stanford University Press, Stanford 2003)

NADINE OBERHUBER and DYRK SCHERFF, 'Was taugt ein Beipackzettel?' FAS, issue of 28 February 2010, 45

JOHn F. O'CONNOR, Good Faith in English Law (Dartmouth, Aldershot 1990)

OFFICE OF FAIR TRADING, Consumers' Knowledge of Their Rights when Buying at the Doorstep or in the Home (May 2004)

STEFAN OSING, Informationspflichten des Versicherers und Abschluss des Versicherungsvertrages (VVW, Karlsruhe 1996)

Claus OTt and HANS-BERND SCHÄFER, 'Die ökonomische Analyse des Rechts: Irrweg oder Chance wissenschaftlicher Rechtserkenntnis?' (1988) JZ 213

SEMIN PARK, The Duty of Disclosure in Insurance Contract Law (Dartmouth, Aldershot 1996)

DAVID S. PENA, Economic Barbarism and Managerialism (Greenwood, Westport 2001)

ARNOLD PICOT, RALF REICHWALD and ROLF WIGAND, Information, Organisation and Management (Springer, Berlin 2008)

RoBert S. PINDYCK and DANIEL L. RUBINFELD, Microeconomics (6th edn Pearson, Upper Saddle River 2005)

PETRA POHLMANN, 'Viel Lärm um nichts: Beratungspflichten nach $\S 6$ VVG und das Verhältnis zwischen Beratungsaufwand und Prämie' (2009) VersR 327

A. Mitchell Polinsky, An Introduction to Law and Economics (3rd edn Aspen Publishers, New York 2003)

RICHARD A. POSNER, 'The Economic Approach to Law' (1975) 53 TexLRev 757 
RICHARD A. POSNER, 'A Theory of Primitive Society, with Special Reference to Law' (1980) 23 JLawEcon 1

RICHARD A. POSNER, The Economics of Justice (Harvard University Press, Cambridge/Mass 1983)

Richard A. POSNER, 'The New Institutional Economics Meets Law and Economics' (1993) 143 JITE 73

RICHARD A. POSNER, 'Rational Choice, Behavioral Economics, and the Law' (1998) 50 StanLRev 1551

RICHARD A. POSNER, Economic Analysis of Law (7th edn Wolters Kluwer, Austin 2007)

PETER PRÄVE, 'Das Kündigungs- und Widerrufsrecht des Versicherungsnehmers bei Neuverträgen' (1991) VW 488

JEFFREY J. RACHLINSKI (ed), Behavioral Law and Economics (Edward Elgar Publishing, Cheltenham 2009)

SAMUEL A. REA, 'The Economics of Insurance Law' (1993) 13 Int'l Rev L \& Econ 145

MARKUS REHBERG, Der Versicherungsabschluss als Informationsproblem: Die Gewährleistung freier Produktwahl in der Privatversicherung (Nomos, Baden-Baden 2003)

MARKUS REHBERG, 'Der staatliche Umgang mit Information' in THOMAS EGER and HANS-BERND SCHÄFER (eds), Ökonomische Analyse der europäischen Zivilrechtsentwicklung (Mohr Siebeck, Tübingen 2007) 284

GEBHARD M. REHM, Aufklärungspflichten im Vertragsrecht (C.H. Beck, Munich 2003)

NORBERT REICH, Understanding EU Law: Objectives, Principles and Methods of Community Law (2nd edn Intersentia, Antwerp 2005)

NORBERT REICH, 'EU Strategies in Finding the Optimal Consumer Law Instrument' (2012) ERCL 1

FRITZ REICHERT-FACILIDES, 'Comparative Insurance Law: General Aspects' in Helmut HeISS and MANDEEP LAKHAN (eds), Principles of European Insurance Contract Law: A Model Optional Instrument (Sellier, Munich 2011) 109

CHRISTINA REIFSCHNEDER, Informationeller Anlegerschutz (Deutscher Universitäts-Verlag, Wiesbaden 2007)

LUCIA A. REISCH and ANDREAS OEHLER, 'Behavioral Economics: Eine neue Grundlage für die Verbraucherpolitik?' (2009) 78 Vierteljahrshefte zur Wirtschaftsforschung 30

PAMARIA REKAITI and ROGER VAN DEN BERGH, 'Cooling-Off Periods in the Consumer Laws of the EC Member States: A Comparative Law and Economics Approach' (2000) 23 JCP 371 
ANDREAS RICHTER, Adverse Selektion auf Versicherungsmärkten: Informationsökonomische Analyse bei exogener, vom Versicherer nicht beobachtbarer Schadenverteilung (VVW, Karlsruhe 1995)

KARL RIESENHUBER, System und Prinzipien des Europäischen Vertragsrechts (de Gruyter, Berlin 2003)

FRANZISKA RISCHKOWSKY and THOMAS DÖRING, 'Consumer Policy in a Market Economy: Considerations from the Perspective of the Economics of Information, the New Institutional Economics as well as Behavioural Economics' (2008) 31 JCP 285

ROLAND RIXECKER, 'Information, Beratung, Versicherung: Zur informationellen Konstruktion eines Rechtsprodukts' in HELMUT RÜSSMANN (ed), FS Gerhard Käfer (juris, Saarbrücken 2009) 273

MARIO J. RIZZO and DOUGLAS GLEN WhitMAN, 'The Knowledge Problem of New Paternalism' (2009) BYU LRev 103

MARIO J. RIZzO and DOUGLAS GLEN WhitMAN, 'Little Brother is Watching You: New Paternalism on the Slippery Slopes' (2009) Ariz LRev 685

HELENA RÖHRICH, Die Dokumentation nach der Beratung nach dem VVG 2008 (VVW 2012)

IOANNIS ROKAS, 'Droit européen du contrat d'assurance' (2010) RGDA 977

WOLGANG RÖMER, ' $\mathrm{Zu}$ den Informationspflichten der Versicherer und ihrer Vermittler' (1998) VersR 1313

WOLFGANG RÖMER, 'Zu ausgewählten Problemen der VVG-Reform nach dem Referentenentwurf vom 13. März 2006 (Teil 1)' (2006) VersR 740

WOLGANG RÖMER, 'Konzept und erste Erfahrungen mit dem Produktinformationsblatt' in CHRISTOPH BRÖMMELMEYER et al., Pflegeversicherung, Risikosteuerung und Versicherungsaufsicht, Europa, Versicherungsvertragsrecht (Nomos, Baden-Baden 2009) 197

FRANCIS D. RosE, Marine Insurance: Law and Practice (LLP, London 2004)

FRANCIS D. RosE, 'Informational Asymmetry and the Myth of Good Faith: Back to Basis' (2007) LMCLQ 181

Don Ross (ed), What People Want: The Concept of Utility from Bentham to Game Theory (University of Cape Town Press, Cape Town 1999)

TANINA Rostain, 'Educating Homo Economicus: Cautionary Notes on the New Behavioral Law and Economics Movement' (2000) 34 Law \& Society Review 973

MichaEl Rothschild and JosePH STIGLITZ, 'Equilibrium in Competitive Insurance Markets: An Essay on the Economics of Imperfect Information' (1976) 90 QJEcon 629 
Paul H. Rubin, 'Law and Economics' in DAVID R. HENDERSON (ed), The Concise Encyclopedia of Economics (2nd edn Liberty Fund, Indianapolis 2007)

GIESEla RÜHL, 'The Common European Sales Law: 28th Regime, 2nd Regime, or 1st Regime?' 19 (2012) Maastricht J. Eur. \& Comp. L. 148 GIESELA RÜHL, 'Information Obligations (Insurance Contracts)' in JÜRGEN BASEDOW, Klaus Hopt und Reinhard ZimmermanN (eds), Max Planck Encyclopedia of European Private Law (OUP, Oxford 2012) 876

William SAMUELSON and Richard ZeCKHAUSER, 'Status Quo Bias in Decision Making' 1 Journal of Risk and Uncertainty (1988) 7

HANS-BERND SCHÄFER, 'Ökonomische Analyse von Aufklärungspflichten' in HANS-BERND SCHÄFER and ClAUS OTT (eds), Ökonomische Probleme des Zivilrechts: Beiträge zum 2. Travemünder Symposium zur ökonomischen Analyse des Rechts (Springer, Berlin 1991) 117

HANS-BERND SCHÄFER, 'Grenzen des Verbraucherschutzes und adverse Effekte des Europäischen Verbraucherrechts' in STEFAN GRUNDMANN (ed), Systembildung und Systemlücken in Kerngebieten des Europäischen Privatrechts (Mohr Siebeck, Tübingen 2000) 559

HANS-BERND SCHÄFER and ClaUs OTT, The Economic Analysis of Civil Law (Edward Elgar Publishing, Cheltenham 2004)

KIM LANE SCHEPPELE, Legal Secrets: Equality and Efficiency in the Common Law (University of Chicago Press, Chicago 1988)

FRED SCHLOSSARECK, Ansprüche des Versicherungsnehmers aus culpa in contrahendo (VVW, Karlsruhe 1994)

AleXANDRA SchMIED, Lord Mansfield: Person und Werk (unpublished doctoral dissertation, University of Münster 1999)

NiCOLE SCHNEIDER, Uberrima Fides: Treu und Glauben und vorvertragliche Aufklärungspflichten im englischen Recht (Duncker \& Humblot, Berlin 2004)

Thomas J. Schoenbaum, 'The Duty of Utmost Good Faith in Marine Insurance Law: A Comparative Analysis of American and English Law' (1998) 29 JMarL\&Com 1

HAROLD M. SCHRODER, MichaEl J. DRIVER and SiEgFried STREUFERT, Human Information Processing: Individuals and Groups Functioning in Complex Social Situations (Holt, Rinehart \& Winston, New York 1967)

NORBERT SCHWARZ, 'Feelings as Information: Moods Influence Judgments and Processing Strategies' in ThOMAS GILOVICH, DALE GRIFFIN and Daniel Kahneman (eds), Heuristics and Biases: The Psychology of Intuitive Judgement (CUP, Cambridge 2002) 534 
HANS-PETER SCHWINTOWSKI, 'Neuerungen im Versicherungsvertragsrecht' (2006) ZRP 139

HANS-PETER SCHWINTOWSKI, 'Erste Erfahrungen mit Kostentransparenz und Produktinformationsblatt nach der VVG-InfoV' (2008) VuR 250

NiCOS SCORDIS and FRANCES KATRISHEN, 'The Changing International Insurance Industry' in YAIR AHARONI (ed), Changing Roles of State Intervention in Services in an Era of Open International Markets (State University of New York Press, Albany 1997) 130

COlin SCOTT and JUliA BLACK, Cranston's Consumers and the Law (3rd edn Butterworths, London 2000)

ERnESTO SCREPANTI and STEFANO ZAMAGNi, An Outline of Economic Thought (2nd edn OUP, Oxford 2005)

Ruth SEFTON-GREEN, 'Duties to Inform versus Party Autonomy: Reversing the Paradigm (from Free Consent to Informed Consent)?' in GERAINT HOWELls, ANDRÉ JANSSEN and REINER SCHUlzE (eds), Information Rights and Obligations: A Challenge for Party Autonomy and Transactional Fairness (Ashgate, Aldershot 2005) 171

Ruth SEFton-GreEn, 'Choice, Certainty and Diversity: Why More is Less’ (2011) ERCL 134

HERSH SHEFRIN, Beyond Greed and Fear: Understanding Behavioral Finance and the Psychology of Investing (OUP, New York 2002)

Peter SiEgelman, 'Adverse Selection in Insurance Markets: An Exaggerated Threat' (2004) 113 Yale LJ 1223

HERBERT A. SimON, 'A Behavioral Model of Rational Choice' (1955) 69 QJEcon 99

Herbert A. Simon, 'Behavioural Economics' in JOHN EATWELl, MurRay Millgate and Peter Newman (eds), The New Palgrave - A Dictionary of Economics: Volume 1 (Macmillan, London 1987)

HERBERT A. SimOn, Models of Bounded Rationality: Empirically Grounded Economic Reason: Vol 3 (MIT Press, Cambridge/Mass 1997)

ANDREW SKINNER (ed), Adam Smith - The Wealth of Nations: Books IV - V (Penguin, London 1999)

JAMES SMETHURST et al., 'Conduct of Business Regulation: A Survey of the UK Regime and a Comparison of the EU and German Law of Risk Management' in JULIAN BURLING and KEVIN LAZARUS (eds), Research Handbook on International Insurance Law and Regulation (Edward Elgar Publishing, Cheltenham 2011) 355

ADAM SMITH, An Inquiry into the Nature And Causes of the Wealth of Nations (W. Strahan and T. Cadell, London 1776)

Ken R. Smith, CathleEn D. Zick, Robert N. Mayer and JeFFrey R. BotKIN, 'Genetic Testing and Adverse Selection in the Market for Life Insurance: Preliminary Findings for the BRCA1 Gene Mutation' in 
Alison K. THOMPSON and RUTH F. CHADwICK (eds), Genetic Information: Acquisition, Access and Control (Kluwer, New York 1999) 57

JAN M. SMITS, The Mind and Method of the Legal Academic (Edward Elgar Publishing, Cheltenham 2012)

MARTIN SOlly, 'Don't Get Caught Out: Pragmatic and Discourse Features of Informational and Promotional Texts in International Healthcare Insurance' (2007) 4 Communication \& Medicine 27

Michael R. Solomon, Consumer Behavior: Buying, Having, and Being (5th edn Prentice Hall, Upper Saddle River 2002)

Claire Souren, The Efficiency of a Cooling-Off Period (Master thesis, University of Hamburg, 2006)

BARIS SOYER, 'Reforming Pre-Contractual Information Duties in Business Insurance Contracts - One Reform too Many?' (2009) JBL 15

JAMES SPEDDing, ROBERT L. Ellis and DOUglas D. HEATH (eds), The Works of Francis Bacon, Vol I (Longman \& Co, London 1857)

MiCHAEL SPENCE, 'Job Market Signaling' (1973) 87 QJEcon 355

GERALD SPINDLER and LARS KLÖHN, 'Koreferat zu Markus Rehberg' in THOMAS EGER and HANS-BERND SCHÄFER (eds), Ökonomische Analyse der europäischen Zivilrechtsentwicklung (Mohr Siebeck, Tübingen 2007) 355

MARTIN SPINDLER, JOACHIM WinTER and STEFFEn HAGMAYER, 'Asymmetric Information in the Market for Automobile Insurance: Evidence From Germany' (2014) JR\&I, 781

MONIKA STAHL, The Principles of European Insurance Law (PEICL) and their Application to Insurance Contracts for Large Risks (Dike, Zurich 2013)

JEFFREY W. STEMPEL, Stempel on Insurance Contracts: Vol 1 (3rd edn Aspen Publishers, Austin 2006)

RODNEY E. STEVENSON, 'Institutional Economics and the Theory of Production' in MARC R. TOOL (ed), Evolutionary Economics, Volume II: Institutional Theory and Policy (M.E. Sharpe, New York 1988) 53

JOHAN STEYN, 'Contract Law: Fulfilling the Reasonable Expectations of Honest Men' (1997) 113 LQR 433

GeORge J. Stigler, 'The Economics of Information' (1961) 69 JPolEcon 213

JosePh E. STiglitz, Whither Socialism? (MIT Press, Cambridge, Mass 1996)

Joseph E. StiglitZ, Globalisation and its Discontents (Allen Lane, London 2002)

JosePH E. STIGLITZ 'Information and the Change in the Paradigm in Economics' in RICHARD ARNOTT, BRUCE GREENWALD, RAVI KANBUR 
and BARRY NALEBUFF (eds), Economics for an Imperfect World: Essays in Honor of Joseph E. Stiglitz (MIT Press, Cambridge, Mass 2003) 569

ANGELA STÖBENER, 'Informations- und Beratungspflichten des Versicherers nach der VVG-Reform' (2007) ZVersWiss 465

Deborah A. Stone, 'Beyond Moral Hazard: Insurance as Moral Opportunity’ (1999) 6 Conn Ins LJ 11

JEFFERY B. STRUCKHOFF, 'The Irony of Uberrimae Fidei: Bad Faith Practices in Marine Insurance' (2004) 29 TulMarLJ 287

JULES STUYCK, 'The Notion of the Empowered and Informed Consumer in Consumer Policy and How to Protect the Vulnerable Under Such a Regime' in GERAINT HOWELLS et al. (eds), The Yearbook of Consumer Law 2007 (Ashgate, Aldershot 2007) 167

JUDITH P. SUMMER, Insurance Law and the Financial Ombudsman Service (Informa, London 2010)

CAss R. Sunstein, 'Behavioral Analysis of Law' (1997) 64 U Chi L Rev 1175

CASs R. Sunstein (ed), Behavioral Law and Economics (CUP, Cambridge 2000)

CASS R. Sunstein and RICHARD H. Thaler, 'Libertarian Paternalism Is Not an Oxymoron' (2003) 70 U Chi L Rev 1159

CASS R. Sunstein, Laws of Fear (CUP, Cambridge 2005) 195

CASS R. SUNSTEIN, 'Empirically Informed Regulation' (2011) 28 U Chi L Rev 1349

CASS R. SUnSTEIN, Simpler: The Future of Government (Simon \& Schuster, New York 2013)

CASS R. SunSTEIN, 'The Storrs Lectures: Behavioral Economics and Paternalism' (2013) 122 Yale LJ 1826

ULRICH VAN SUNTUM, The Invisible Hand: Economic Thought Yesterday and Today (Springer, Berlin 2005)

GERALD SwABY, 'Insurance Law: Fit for Purpose in the Twenty-First Century?' (2010) 52 IJLMA 21

JOCHEN TAUPITZ, 'Macht und Ohnmacht der Verbraucher auf dem dekontrollierten europäischen Versicherungsmarkt' (1995) VersR 1125

GunTHER TEUBNER, 'Legal Irritants: Good Faith in British Law or How Unifying Law Ends Up in New Divergences' (1998) 61 MLR 11

RICHARD H. THALER, 'Toward a Positive Theory of Consumer Choice' (1980) 1 JEconBehavOrgan 39

RICHARD H. THALER, Quasi Rational Economics (Russell Sage, New York 1994)

MichAEL THEIL, Versicherungsentscheidungen und Prospect Theory: Die Risikoeinschätzung der Versicherungsnehmer als Entscheidungsgrundlage (Springer, Vienna 2002) 
MANFRED TIETZEL, 'Kommentar' in Claus OTt and HANS-BERND SCHÄFER (eds), Effiziente Verhaltenssteuerung und Kooperation im Zivilrecht (Mohr Siebeck, Tübingen 1997) 103

ACHIM TIFFE, 'Verbraucherpolitik im Bereich der Finanzdienstleistungen muss mehr sein als Bereitstellung von Information' (2009) 78 Vierteljahrshefte zur Wirtschaftsforschung 110

ROBERT D. TOLLISON, 'Homo Economicus' in CHARLES K. ROWLEY and FRIEDRICH SCHNEIDER (eds), The Encyclopedia of Public Choice (Springer US, New York 2003) 281

DENNIS H. Tootelian, 'Potential Impact of "Cooling-Off" Laws on Direct-to-Home Selling' (1975) 51 Journal of Retailing 61

LEON E. TRAKMAN, 'The Unharnessed Insurer: A Foreboding Presence' (1981) 31 UTLJ 318

Michael J. TRebilcock, The Common Law of Restraint of Trade: A Legal and Economic Analysis (Carswell, Toronto 1986)

Michael J. TREBILCOCK, The Limits of Freedom of Contract (Harvard University Press, Cambridge/Mass 1993)

FRANCIS A. TRINDADE, 'Case Comment: The Skandia Case in the House of Lords' (1991) 107 LQR 24

J.D. TRouT, 'Paternalism and Cognitive Bias' (2005) 24 Law and Philosophy 393

GORDON TUlLOCK, 'Economic Imperialism' in JAMES M. BUCHANAN and ROBERT TOLLISION (eds), Theory of Public Choice (University of Michigan Press, Ann Arbor 1972) 317

Amos TVERSKY and DANiEl Kahneman, 'Rational Choice and the Framing of Decisions' (1986) 59 J Bus 251

AMOS TVERSKY and DANIEL KAHNEMAN, 'Loss Aversion in Riskless Choice: A Reference-Dependent Model' (1991) 106 QJEcon 1039

Christian TwIGG-FLESNER, 'Good-Bye Harmonsiation by Directives, Hello Cross-Border only Regulation? A Way Forward to EU Consumer Contract Law' (2011) ERCL 235

ThOMAS S. Ulen, 'The Future of Law and Economics' in FABRIzIO CAFAGGI,

W.R. VANCE, 'The Early History of Insurance Law' (1908) 8 ColumLRev 1

WynAND VAN DE Ven and René van Vliet, 'Consumer Information Surplus and Adverse Selection in Competitive Health Insurance Markets: An Empirical Study' (1995) 14 JHealthEcon 149

ALESSANDRO VerCELLI, 'Rationality, Learning and Complexity: From the Homo Economicus to the Homo Sapiens' in Massimo Salzano and DaVID Colander (eds), Complexity Hints for Economic Policy (Springer Italy, Milan 2007) 3 
AlEXANDER VON VOGEL, 'If you Understand Everything, you must be Misinformed: Die Informationspflicht des Gewerbetreibenden nach der Richtlinie über unlautere Geschäftspraktiken' in KARL RIESENHUBER and YUKO NiSHITANI (eds), Wandlungen oder Erosion der Privatautonomie? (de Gruyter, Berlin 2007) 135

StUART Vyse, Going Broke: Why Americans Can't Hold on to their Money (OUP, Oxford 2008)

GERHARD WAGNER, 'Lügen im Vertragsrecht' in REINHARD ZIMMERMANN (ed), Störungen der Willensbildung bei Vertragsschluss (Mohr Siebeck, Tübingen 2007) 59

GERHARD WAGNER, '(Un)insurability and the Choice between Market Insurance and Public Compensation Systems' in WILlEM H. VAN BoOM and Michael FAURE (eds), Shifts in Compensation Between Private and Public Systems (Springer, Vienna/New York 2007) 87

DANIELA WEBER-REY, 'Harmonisation of European Insurance Contract Law' in Stefan Vogenauer and Stephen Weatherill (eds), The Harmonisation of European Contract Law (Hart, Portland 2006), 207

THOMAS WEIN, Wirkungen der Deregulierung im deutschen Versicherungsmarkt: Eine Zwischenbilanz (VVW, Karlsruhe 2001)

NeIL D. WeInsteIn, 'Unrealistic Optimism About Future Life Events' (1980) 39 Journal of Personality and Social Psychology 806

NEIL D. WEINSTEIN, 'Reducing Unrealistic Optimism About Illness Susceptibility' (1983) 2 Health Psychology 11

DOMENIK HENNING WENDT, Zum Widerruf im Versicherungsvertragsrecht: Motive, Probleme und Lösungen (VVW, Karlsruhe 2013)

MANFRED WERBER, 'Alte und neue Informations- und Beratungspflichten des Versicherers und des Vermittlers' (1994) ZVersWiss 321

Simon WhitTAKER and REInHARD Zimmermann, 'Good Faith in European Contract Law: Surveying the Legal Landscape' in REINHARD ZIMMERMANN and SimON WhiTTAKER (eds), Good Faith in European Contract Law (CUP, Cambridge 2000) 7

MATTHIAS WIERSICH, Der Einfluss von Emotionen auf Versicherungsentscheidungen (Doctoral thesis, University of Erlangen-Nürnberg, 2013)

ThOMAS WiLhelmsson, 'European Rules on Pre-Contractual Information Duties' (2005) 6 ERA Forum 16

ThOMAS WiLHELMSSON, 'The Informed Consumer $v$ the Vulnerable Consumer in European Unfair Commercial Practices Law - A Comment' in GERAINT Howells et al. (eds), The Yearbook of Consumer Law 2007 (Ashgate, Aldershot 2007) 211

Oliver Williamson, 'Transaction Cost Economics Meets Posnerian Law and Economics' (1993) 143 JITE 99 
ALEXANDER WIMMER, Möglichkeiten der Effizienzsteigerung für die private und gesetzliche Krankenversicherung: Analyse unter Berücksichtigung der Leistungsfähigkeit internationaler Krankenversicherungssysteme (VVW, Karlsruhe 2008)

HwEE YING YeO, 'Of Reciprocity and Remedies - Duty of Disclosure in Insurance Contracts' (1991) 11 LS 131

STEFAN ZEISBERGER, The Impact of Colors and Axes on Risk Perception and Risk Taking (unpublished manuscript)

DANIEL ZIMMER, 'Vom Informationsmodell zu Behavioral Finance' (2014) JZ 714 